\title{
Vitamin C Cytotoxicity and Its Effects in Redox Homeostasis and Energetic Metabolism in Papillary Thyroid Carcinoma Cell Lines
}

\author{
Laura Tronci ${ }^{1}{ }^{\oplus}$, Gabriele Serreli ${ }^{1, *}{ }^{\circledR}$, Cristina Piras ${ }^{1} \oplus$, Daniela Virginia Frau ${ }^{1}$, Tinuccia Dettori ${ }^{1}$, \\ Monica Deiana ${ }^{1} \mathbb{1}$, Federica Murgia ${ }^{1}$, Maria Laura Santoru ${ }^{1}$, Martina Spada ${ }^{1}$, Vera Piera Leoni ${ }^{1}$, \\ Julian Leether Griffin ${ }^{2}$, Roberta Vanni ${ }^{1}{ }^{1}$, Luigi Atzori ${ }^{1,+}+{ }^{-}$and Paola Caria ${ }^{1,+}$
}

1 Department of Biomedical Sciences, University of Cagliari, Cittadella Universitaria, SS 554, km 4.5, 09042 Monserrato, Italy; lauratronci90@gmail.com (L.T.); cristina.piras@unica.it (C.P.); dvfrau@unica.it (D.V.F.); dettorit@unica.it (T.D.); mdeiana@unica.it (M.D.); federica.murgia@unica.it (F.M.); marialaurasantoru@gmail.com (M.L.S.); martina.spada@unica.it (M.S.); vleoni@unica.it (V.P.L.); vanni@unica.it (R.V.); latzori@unica.it (L.A.); paola.caria@unica.it (P.C.)

2 Department of Biochemistry \& Cambridge Systems Biology Centre, University of Cambridge, Cambridge CB1 9NL, UK; julian.griffin@imperial.ac.uk

* Correspondence: gabriele.serreli@unica.it; Tel.: +39-070-675-4185; Fax: +39-070-675-4032

+ Equally contributing.

check for updates

Citation: Tronci, L.; Serreli, G.; Piras, C.; Frau, D.V.; Dettori, T.; Deiana, M.; Murgia, F.; Santoru, M.L.; Spada, M.; Leoni, V.P.; et al. Vitamin C

Cytotoxicity and Its Effects in Redox Homeostasis and Energetic

Metabolism in Papillary Thyroid Carcinoma Cell Lines. Antioxidants 2021, 10, 809. https://doi.org/ 10.3390/antiox10050809

Academic Editors: Stefania

Pizzimenti, Giuliana Muzio and Giuseppina Barrera

Received: 21 April 2021

Accepted: 15 May 2021

Published: 20 May 2021

Publisher's Note: MDPI stays neutral with regard to jurisdictional claims in published maps and institutional affiliations.

Copyright: (C) 2021 by the authors Licensee MDPI, Basel, Switzerland. This article is an open access article distributed under the terms and conditions of the Creative Commons Attribution (CC BY) license (https:/ / creativecommons.org/licenses/by/ $4.0 /)$.
Abstract: High-dose of vitamin C (L-ascorbic acid, ascorbate) exhibits anti-tumoral effects, primarily mediated by pro-oxidant mechanisms. This cytotoxic effect is thought to affect the reciprocal crosstalk between redox balance and cell metabolism in different cancer types. Vitamin $C$ also inhibits the growth of papillary thyroid carcinoma (PTC) cells, although the metabolic and redox effects remain to be fully understood. To shed light on these aspects, PTC-derived cell lines harboring the most common genetic alterations characterizing this tumor were used. Cell viability, apoptosis, and the metabolome were explored by 3-(4,5-dimethylthiazol-2-yl)-2,5-diphenyltetrazolium bromide test (MTT), flow cytometry, and UHPLC/MS. Changes were observed in redox homeostasis, with increased reactive oxygen species (ROS) level and perturbation in antioxidants and electron carriers, leading to cell death by both apoptosis and necrosis. The oxidative stress contributed to the metabolic alterations in both glycolysis and TCA cycle. Our results confirm the pro-oxidant effect of vitamin C as relevant in triggering the cytotoxicity in PTC cells and suggest that inhibition of glycolysis and alteration of TCA cycle via $\mathrm{NAD}^{+}$depletion can play an important role in this mechanism of PTC cancer cell death.

Keywords: vitamin C; PTC cells; ROS; cell metabolism; TCA cycle; antioxidants; glycolysis; anticancer effects

\section{Introduction}

Several in vitro and in vivo studies have shown that a high dose of vitamin $C$ exhibits antitumor effects [1-3], and this cytotoxicity is mediated by the accumulation of hydrogen peroxide $\left(\mathrm{H}_{2} \mathrm{O}_{2}\right)$, resulting in the depletion of intracellular antioxidants [4-7]. Particularly, the accumulation of $\mathrm{H}_{2} \mathrm{O}_{2}$ leads to the conversion of the reduced glutathione (GSH) into the oxidized form (GSSG), resulting in oxidative stress and cell damage [6]. It is becoming clear that redox perturbations and altered energy metabolism are hallmarks of cancer, playing a fundamental role in the development, progression, and survival of cancer cells [8]. Previous studies showed the effect of vitamin $C$ on the viability of breast and colon cancer cells, by inhibiting energetic processes and consequently ATP production [4,9]. The selective action of high levels of vitamin $\mathrm{C}$ on cultured cancer cells harboring KRAS or BRAF mutations has been demonstrated for the first time in colon cancer, which commonly harbors these genetic mutations [9]. This observation provided a mechanistic rationale for 
exploring the therapeutic use of vitamin $C$ in treating cancer cells with these mutations. Interestingly, KRAS or BRAF mutations, as well as RET/PTC rearrangements, characterize the vast majority of papillary thyroid carcinoma (PTC) [10]. These molecular changes activate the MAPK/ERK and PI3/AKT pathways, which are affected in thyroid cancer cells exposed to a high dose of vitamin C [11]. Nevertheless, the exact role of vitamin C in perturbing metabolism in PTC cancer cells is still poorly understood. PTC accounts for $80-85 \%$ of differentiated thyroid cancer and, in general, it has a good prognosis and a relatively low aggressiveness [12]. However, disease progression and patient death may occur due to poor response or resistance to standard treatment. In the present research, the anti-tumoral mechanism of vitamin C in a PTC in vitro model has been investigated by exploring oxidative effects and metabolic alterations. The selected PTC-derived cell lines, all sharing $h T E R T$ promoter mutation, also harbored $B R A F^{V 600 E}$ and TP53 mutations (B-CPAP cell line), BRAF V600E mutation (K1 cell line) and RET/PTC rearrangement (TPC-1 cell line) $[13,14]$. A human SV40 T large antigen-immortalized thyroid cell line (Nthy-ori 3-1) was used as control. Our results show, for the first time by the analysis of metabolomic profiles, that the pro-oxidant effect of vitamin $C$ in $B R A F$ mutant thyroid cancer cells induces the inhibition of glycolysis and alteration of TCA cycle via NAD+ depletion, leading to cell death.

\section{Materials and Methods}

\subsection{Chemical and Reagents}

L-ascorbic acid (vitamin C, catalog number A4544), dimethyl sulfoxide (DMSO), acetonitrile and N-acetyl-L-cysteine (NAC, catalog number A9165) were purchased from Merck (Milan, Italy). Vitamin C and NAC stock solutions (concentration of $0.5 \mathrm{M}$ ) were prepared freshly in sterile ultrapure water before each cell treatment.

\subsection{Cell Culture}

PTC-derived TPC-1 and B-CPAP cell lines were kindly provided by Dr. Fusco (Medical School, University Federico II of Naples, Naples, Italy), while the K1 cell line and Nthyori3-1, (Simian Virus 40 (SV40)-immortalized normal human thyrocytes) cell lines were purchased from the Health Protection Agency Culture Collections (Health Protection Agency Culture Collections; 2011 http:/ / www.hpa.org.uk, last accessed on 20 May 2021). All cell lines were grown as monolayers in Dulbecco's Modified Eagle's Medium/Ham's F-12 (DMEM/F12) supplemented with 10\% fetal bovine serum (FBS, Life Technologies, Milan, Italy), $100 \mathrm{UI} / \mathrm{mL}$ penicillin and $100 \mu \mathrm{g} / \mathrm{mL}$ streptomycin (Sigma-Aldrich, Milan, Italy), at $37^{\circ} \mathrm{C}$ in a humidified $5 \% \mathrm{CO}_{2}$ atmosphere.

\subsection{MTT Viability Test}

Vitamin C cytotoxicity was measured using the MTT (3-(4,5-dimethylthiazol-2-yl) -2,5-diphenyltetrazolium bromide) assay as follows. The cells were seeded at the density of $7.5 \times 10^{3}$ cells, in a 96-well plate and incubated for $24 \mathrm{~h}$. Then, vitamin C was added at six different concentrations (0.1-15 mM) and cells were further incubated for $24 \mathrm{~h}$ and $48 \mathrm{~h}$, to evaluate the sub-lethal and lethal concentration of vitamin C. After incubation, vitamin $C$ was replaced with $50 \mu \mathrm{L}$ of MTT reagent $(1 \mathrm{mg} / \mathrm{mL}$ in DMEM/F12), and cells were incubated for additional $4 \mathrm{~h}$. The resulting formazan crystals were dissolved in $100 \mu \mathrm{L}$ of DMSO. The absorbances were measured at $570 \mathrm{~nm}$ using a TECAN microplate reader (Infinite 200, Tecan, Salzburg, Austria). Viability data were reported as \% of control (untreated cells) for each cell line.

\subsection{Apoptosis Assay}

To investigate cell death induced by vitamin $C$ treatment, a flow cytometric analysis using the cell apoptosis kit Annexin V/PropidiumIodide (PI) double staining uptake (Life Technologies, Monza, Italy) was used. Control and PTC-derived cells, at the density of $5 \times 10^{4}$ cells $/ \mathrm{mL}$, were seeded in 6-well plates (Corning, Tewksbury, MA, USA) with 
complete DMEM/F12. First, the cells were treated with $5 \mathrm{mM}$ vitamin $\mathrm{C}$ for B-CPAP and K1, $10 \mathrm{mM}$ for TPC-1 and $15 \mathrm{mM}$ for NThy-ori3-1 for $48 \mathrm{~h}$. Next, all cell lines were treated with $5 \mathrm{mM}$ of vitamin $C$ and with $10 \mathrm{mM}$ of NAC, or with NAC and vitamin $C$ together for $48 \mathrm{~h}$. Cells were washed once with PBS 1X and stained, according to the kit's protocol. Stained cells were then analyzed by flow cytometry, measuring the fluorescence emission at 530 and $620 \mathrm{~nm}$ using $488 \mathrm{~nm}$ excitation laser (MoFloAstrios EQ, Beckman Coulter). Cell apoptosis was analyzed using Software Summit Version 6.3.1.1, Beckman Coulter. For the following experiments, $5 \mathrm{mM}$ of vitamin $\mathrm{C}$ was used in all cell lines.

\subsection{Determination of Intracellular ROS Production}

To detect intracellular ROS production, PTC-derived and control cells were seeded in 96-well plates $\left(7.5 \times 10^{3}\right)$ and grown for $24 \mathrm{~h}$. Cells were then washed with PBS $1 \mathrm{X}$ solution and incubated for $30 \mathrm{~min}$ with $2^{\prime}, 7^{\prime}$-dichlorofluorescin diacetate probe $\left(\mathrm{H}_{2}\right.$-DCFDA) (Merck, Milan, Italy) $(10 \mu \mathrm{M})$, as previously described [15,16]. H $\mathrm{H}_{2}$-DCF-DA was then removed, and cells were treated with vitamin $\mathrm{C}(5 \mathrm{mM})$, with the oxidant tert-butyl hydroperoxide (TBH $2.5 \mathrm{mM})$, as a positive control, with NAC (10 mM) as an antioxidant, and with combinations of NAC $+\mathrm{TBH}$ or vitamin $\mathrm{C}$. After $1 \mathrm{~h}$ of incubation, excess of $\mathrm{H}_{2}-$ DCF-DA was removed and replaced with PBS and then ROS levels were measured by using a microplate reader (Infinite 200, Tecan, Salzburg, Austria) at a controlled temperature of $37^{\circ} \mathrm{C}$. The measurement was performed using an excitation of $490 \mathrm{~nm}$ and an emission of $520 \mathrm{~nm}$. ROS production was evaluated for $2 \mathrm{~h}$ and monitored taking readings at intervals of $5 \mathrm{~min}$.

\subsection{Determination of Intracellular Aminothyols}

Reduced glutathione (GSH), oxidized glutathione GSSG, cysteine (Cys), and cystine (CySS) levels were determined with a high-performance liquid chromatography coupled with an electrochemical detector (HPLC-ECD), as previously described [17-19]. In detail, cells were seeded in 6-well plates at the density of $1 \times 10^{5}$ cells $/ 2 \mathrm{~mL}$ and incubated for $24 \mathrm{~h}$. Cells were then treated with vitamin $C(5 \mathrm{mM})$ with or without NAC $(10 \mathrm{mM})$ co-incubation and incubated for $24 \mathrm{~h}$. After the incubation, cells were scraped and extracted with $150 \mu \mathrm{L}$ of $10 \%$ meta-phosphoric acid and $150 \mu \mathrm{L}$ of $0.05 \%$ trifluoroacetic acid (TFA) (Merck, Milan, Italy) solution. After centrifugation, $10 \mu \mathrm{L}$ of supernatant were collected for the protein determination and the remaining part was injected into the HPLC system. GSH, GSSG, Cys, and CySS amounts were measured using an HPLC (Agilent 1260 infinity, Agilent Technologies, Palo Alto, CA, USA) equipped with an electrochemical detector (DECADE II Antec, Leyden, The Netherlands) and an Agilent interface 35900E. A calibration curve was created using standards of GSH, GSSG, Cys, and CySS (Merck, Milan, Italy), injected with different concentrations. Data were collected and expressed as a ratio between ng of GSH, GSSG, Cys, and CySS, and $\mu \mathrm{g}$ of total proteins.

\subsection{Aqueous Metabolites Extraction}

Cells were seeded in Petri dishes $(100 \mathrm{~mm})$ at the density of $1.8 \times 10^{5} / \mathrm{mL}$ cells and grown for $24 \mathrm{~h}$. Then, cells were treated with $5 \mathrm{mM}$ of vitamin $\mathrm{C}$ and further incubated for $24 \mathrm{~h}$. Cells were harvested by scraping with a mixture of cold methanol and water (80:20\%) for the polar metabolites extraction as previously described [20]. Cells were then detached and collected in Eppendorf ${ }^{\mathrm{TM}}$ tubes. To ensure the complete lysis of the cells, the extraction was combined with 10 min of ultrasonic treatment at a controlled temperature $\left(4^{\circ} \mathrm{C}\right)$. Cell suspensions were centrifuged at $4500 \mathrm{rpm}$ for $30 \mathrm{~min}$ at $4{ }^{\circ} \mathrm{C}$. The upper aqueous phase was separated, aliquoted in Eppendorf tubes, and dried in an Eppendorf ${ }^{\mathrm{TM}}$ Concentrator Plus overnight.

\subsection{Glucose Uptake Assay}

PTC-derived cells were seeded in 96-well plates $\left(1 \times 10^{5}\right.$ cells $\left./ \mathrm{mL}\right)$ and grown in DMEM/F12 medium for $24 \mathrm{~h}$ at $37^{\circ} \mathrm{C}$. Then, cells were rinsed with PBS (pH 7.4) (Euroclone, 
Pero, ltaly) and treated simultaneously with the fluorescently-tagged glucose derivative 2-[N-(7-nitrobenz-2-oxa-1,3-diazol-4-yl)amino]-2-deoxy-Dglucose (2-NBDG, N13195; ThermoFisher, Waltham, MA, USA) $(50 \mu \mathrm{M})$ and with vitamin C (5 mM) in PBS for $30 \mathrm{~min}$. Afterwards, external 2-NBDG and the excess of vitamin $C$ were washed off and replaced with $100 \mu \mathrm{L}$ of fresh PBS. Relative glucose uptake was then measured by reading the fluorescence using a micro plate reader (Infinite 200, Tecan, Salzburg, Austria) at a controlled temperature of $37^{\circ} \mathrm{C}$. The measurements were performed using an excitation wavelength of $485 \mathrm{~nm}$ and an emission wavelength of $530 \mathrm{~nm}$.

\subsection{Ultra High-Performance Liquid Chromatography-Tandem Mass Spectrometry}

Aqueous dried samples were quantified using an ultra-performance liquid chromatography coupled with a TSQ Quantiva ${ }^{\mathrm{TM}}$ Triple Quadrupole Mass Spectrometer (UHPLC/MS) (ThermoFisher, Waltham, MA, USA)in two targeted analysis as previously described [20]. Briefly, for the first analysis samples were reconstituted with $200 \mu \mathrm{L}$ of acetonitrile:water (7:3) with ammonium carbonate 0.1 M (Sigma Aldrich, Gillingham, Dorset, UK) and the LC column used was a BEH amide HILIC column $(100 \times 2.1 \mathrm{~mm}, 1.7 \mu \mathrm{m}$; Waters Ltd., Elstree, Borehamwood, UK). For the second targeted analysis, samples were reconstituted in water with $0,1 \%$ of formic acid (Sigma Aldrich, Gillingham, Dorset, UK) and injected using a reverse phase column ACE C18-pfp $(150 \times 2.1 \mathrm{~mm}, 2 \mu \mathrm{m}$; Advanced Chromatography Technologies. Aberdeen, Scotland). Aqueous metabolites were acquired through selected reaction monitoring (SRM) mass spectrometry analysis using an internal standard mix with: $\left[{ }^{13} \mathrm{C},{ }^{15} \mathrm{~N}\right] \mathrm{L}$-proline, L-leucine-d10, L-Valine-d8, L-phenylalanine $\mathrm{d} 5$, Succinate- ${ }^{13} \mathrm{C}$ and Serotonine-d4 (Sigma Aldrich, Gillingham, Dorset, UK), and $\left[{ }^{13} \mathrm{C},{ }^{15} \mathrm{~N}\right] \mathrm{L}$-glutamate (Cambridge Isotope Laboratories, Andover, MA, USA) $(10 \mu \mathrm{M}$ each). The Xcalibur software (Thermos fisher scientific, Waltham, MA, USA) was used for data acquisition. Putative recognition of all detected metabolites was performed using a targeted MS/MS analysis and reference to standards for accurate retention times. Peak areas, for each detected metabolite, were then normalized by total area and reported as ranks in the bar graph.

\subsection{Statistical Analysis}

Data were analyzed using the GraphPad Prism v5.0 software (La Jolla, CA, USA). Statistical analysis of the experimental results was performed using unpaired Student $t$-Test. Data are presented as means \pm Standard Deviation. All experiments were performed three times independently, each time in triplicate to confirm the results.

\section{Results}

\subsection{Cytotoxicity Induced by Vitamin C Treatment}

Cytotoxicity of vitamin C in PTC-derived cell lines and control cells was analyzed by MTT assay. All cell lines were exposed to different doses of vitamin C $(0.5 \mathrm{mM}, 1 \mathrm{mM}$, $2.5 \mathrm{mM}, 5 \mathrm{mM}, 10 \mathrm{mM}$, and $15 \mathrm{mM}$ ) and cell growth was evaluated after 24 and $48 \mathrm{~h}$. Cell viability was significantly reduced after $48 \mathrm{~h}$ of vitamin C (Figure 1), whereas viability was not affected after $24 \mathrm{~h}$ incubation (data not shown). B-CPAP and K1 cells were the most sensitive $(5 \mathrm{mM})$, followed by TPC-1 $(10 \mathrm{mM})$. Nthy-ori3-1 cells were the least sensitive to vitamin $\mathrm{C}(15 \mathrm{mM})$ (Table 1$)$. Annexin $\mathrm{V} /$ Propidium Iodide assay on cells exposed to vitamin $C$ demonstrated that cell death mechanisms involved both apoptosis and necrosis. After $48 \mathrm{~h}$ exposure to different concentrations of vitamin C ( $5 \mathrm{mM}$ for B-CPAP and K1, $10 \mathrm{mM}$ for TPC-1, $15 \mathrm{mM}$ for Nthy-ori3-1), a significant increase of necrosis was observed in all PTC-derived cells $(70.05 \%, 81.32 \%$, and $72.93 \%$ for TPC- 1 , K1, and B-CPAP treated cell lines, respectively). Moreover, a slight increase in apoptosis was induced only in B-CPAP cell line after vitamin C exposure (6.3\% untreated vs $20.73 \%$ treated cells). On the contrary, in Nthy-ori3-1 cells only apoptosis was detected after vitamin C treatment (Figure 2). 


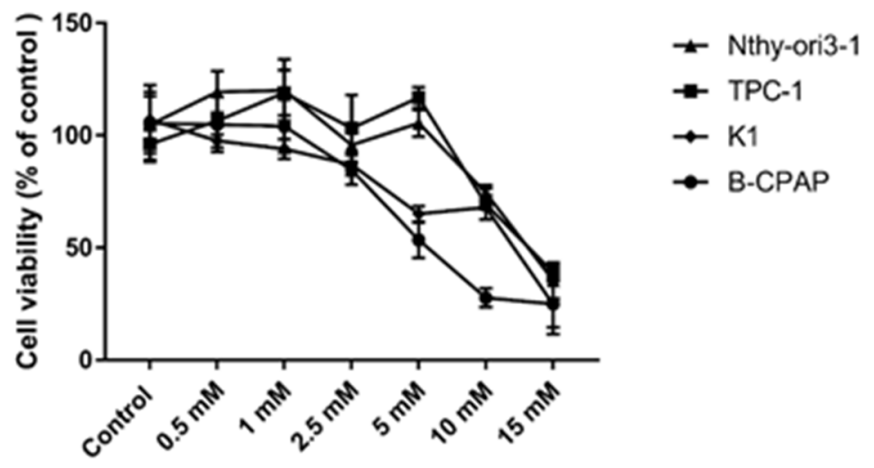

Figure 1. Viability of cells treated with vitamin C $(0.5-15 \mathrm{mM})$ for $48 \mathrm{~h}$ analyzed by MTT assay. Data are expressed as $\%$ of the untreated cells (control) \pm SD. All experiments were performed three times independently.

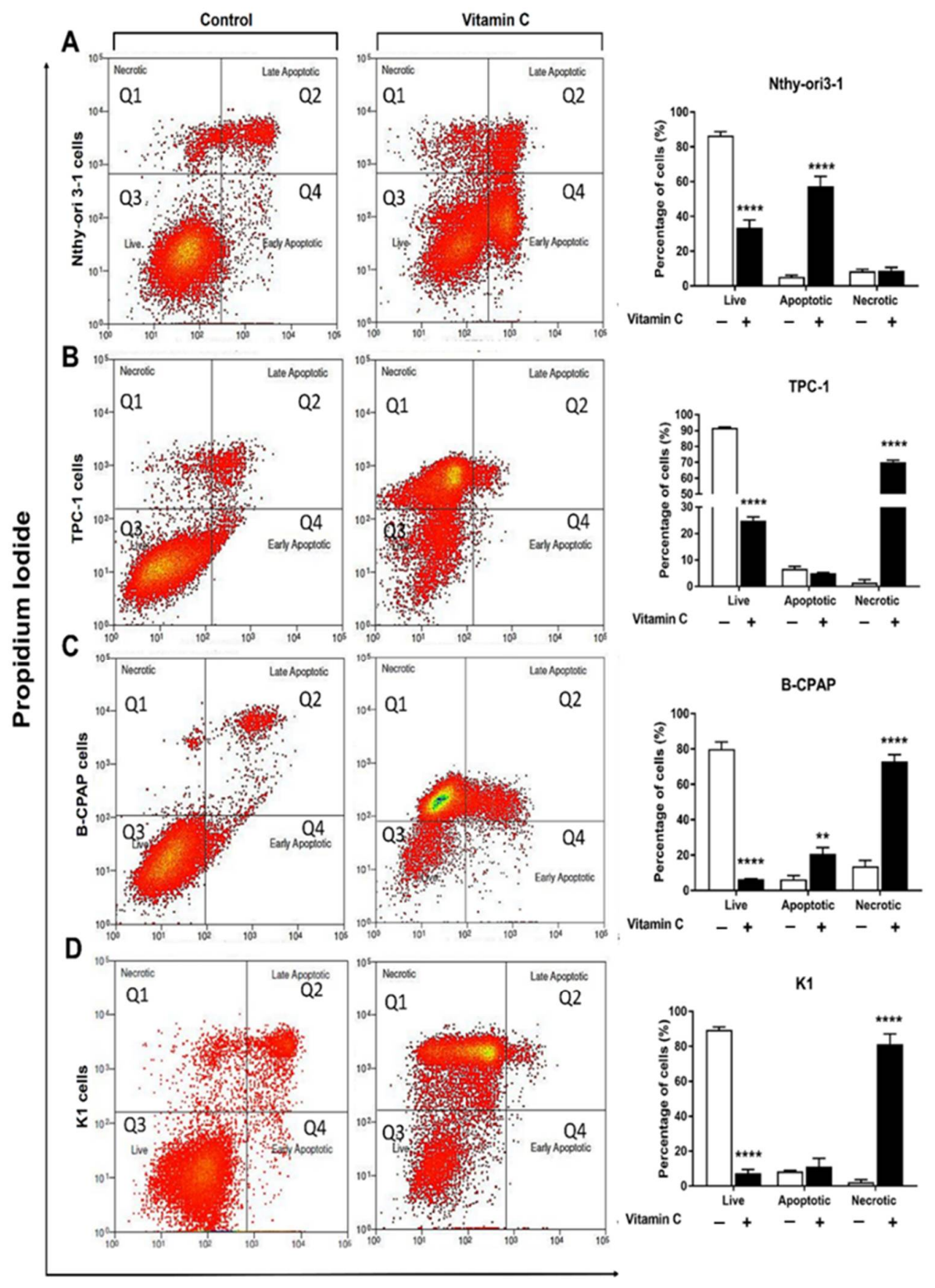

Annexin V - FITC

Figure 2. Percentage of live, apoptotic, and necrotic cells measured by flow cytometry using the 
PI-annexin V assay. Dot plots showing cell death in all cell lines treated for $48 \mathrm{~h}$ with different doses of vitamin C: Nthy-ori 3-1 with $15 \mathrm{mM}$ (A), TPC-1 with $10 \mathrm{mM}$ (B), K1 and B-CPAP with $5 \mathrm{mM}$ (C,D). Bar graphs are representative of three experiments and show the percentage of live, apoptotic (early apoptotic and late apoptotic cells), and necrotic cells. Data are expressed as the Mean of $\%$ cells \pm SD. All experiments were performed three times independently, each time in triplicate, to confirm the results. Statistical analyses were performed by Student $t$-test. Statistical differences vs. control are expressed with superscript symbols: ${ }^{* *} p<0.01 ;{ }^{* * * *} p<0.0001$.

Table 1. Concentration of vitamin C able to induce 50\% of cell death in PTC-derived and control cells.

\begin{tabular}{cc}
\hline Cell Lines & Vitamin C Concentration \\
\hline B-CPAP & $5 \mathrm{mM}$ \\
K1 & $5 \mathrm{mM}$ \\
TPC-1 & $10 \mathrm{mM}$ \\
Nthy-ori3-1 & $15 \mathrm{mM}$ \\
\hline
\end{tabular}

\subsection{Oxidative Stress Induced by Vitamin C in PTC-Derived Cells}

To confirm the pro-oxidant vitamin $C$ effect, changes in the redox balance were assessed by measuring intracellular oxidants and antioxidant species in cells exposed to $5 \mathrm{mM}$ vitamin C (the lowest observed cytotoxic concentration for 2 out of 3 PTC-derived cell lines). tert-butyl hydroperoxide (TBH) was used as oxidant positive control and N-acetyl-Lcysteine (NAC) as an antioxidant. Vitamin C-treated B-CPAP cells had significantly higher ROS levels than untreated cells, whereas no difference was observed in K1, TPC-1, and control cells, compared to the corresponding untreated cells. Overall, in all cell lines, NAC was able to reduce ROS levels as expected (Figure 3), and the combined exposure to vitamin $\mathrm{C}$ and NAC showed similar ROS level compared to those cells treated only with NAC.
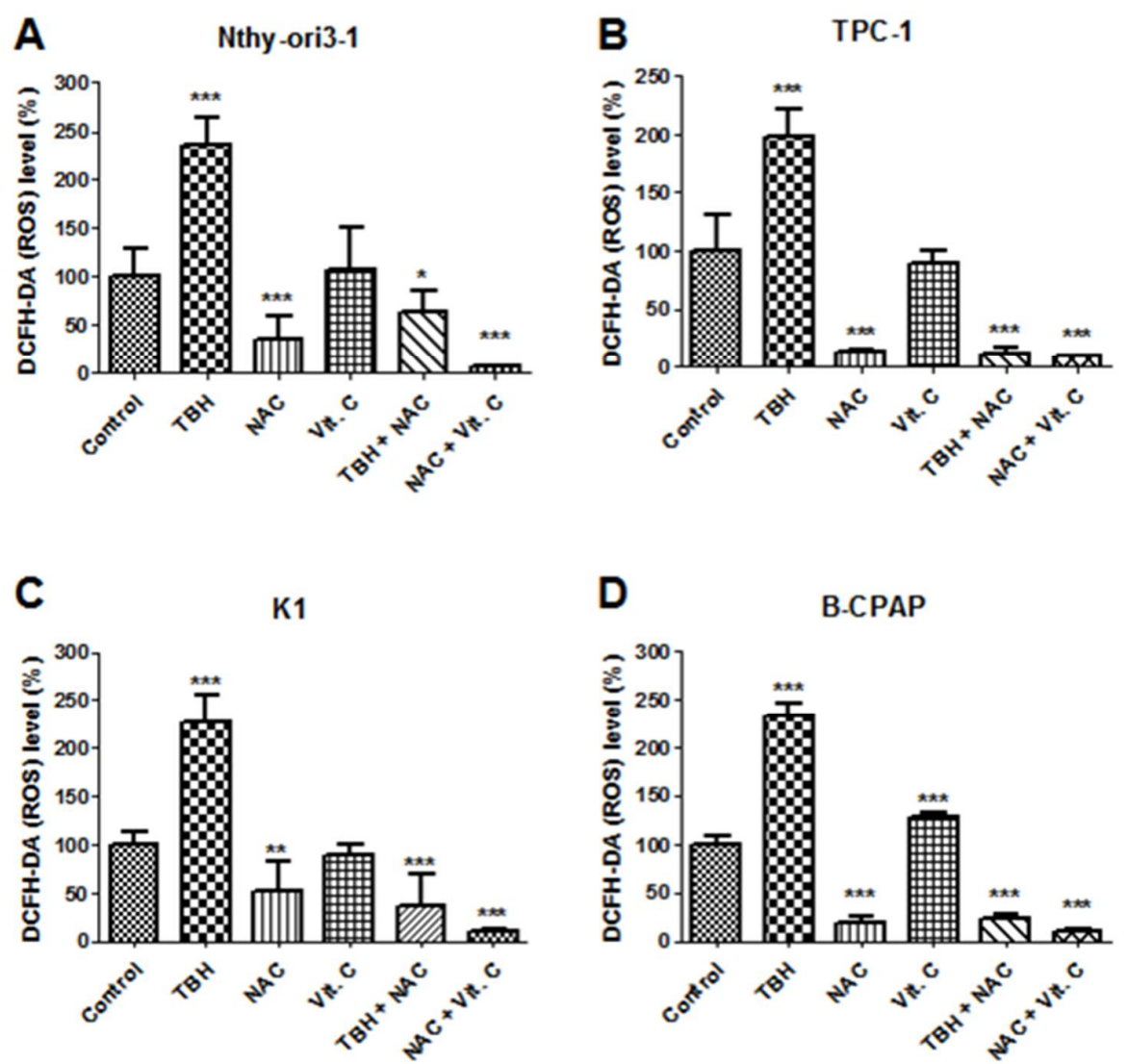

Figure 3. Reactive oxygen species (ROS) levels in PTC-derived cell lines and non-tumoral thyroid cell line, expressed as \% of fluorescence of control (untreated cells for each cell line) after treatment 
with vitamin C $5 \mathrm{mM}$, TBH $2.5 \mathrm{mM}$, NAC $10 \mathrm{mM}$ and a combination of TBH+NAC and NAC + vitamin C. (A) Nthy-ori3-1, (B) TPC-1 (C) K1 (D) B-CPAP cell lines. Statistical analysis was performed by Student $t$-Test. Results were considered significant vs. control when ${ }^{*} p<0.05,{ }^{* *} p<0.01$, and *** $p<0.001$.

Redox perturbation was further investigated by measuring intracellular antioxidant species. While vitamin C treatment significantly decreased the GSH/GSSG ratio only in $\mathrm{B}-\mathrm{CPAP}$ cells, Cys / CySS ratio was significantly reduced in $\mathrm{K} 1$ cells as well as in B-CPAP cells (Figure 4). Moreover, NAC was able to counteract the vitamin C-induced reduction of GSH/GSSG antioxidant species in B-CPAP cells and decrease in Cys/CySS ratio in K1 cells (Figure 4).

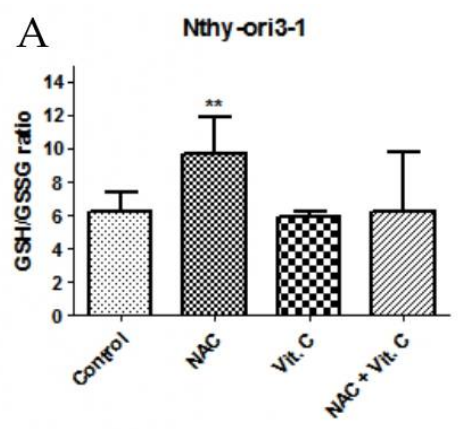

K1
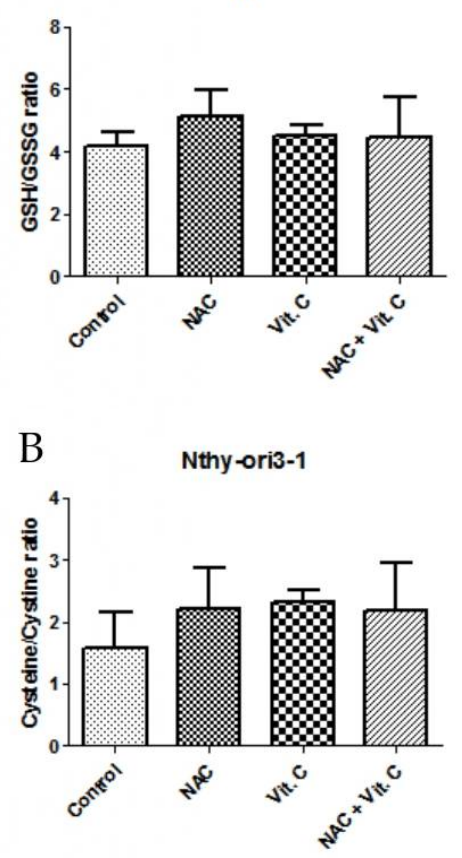

K1

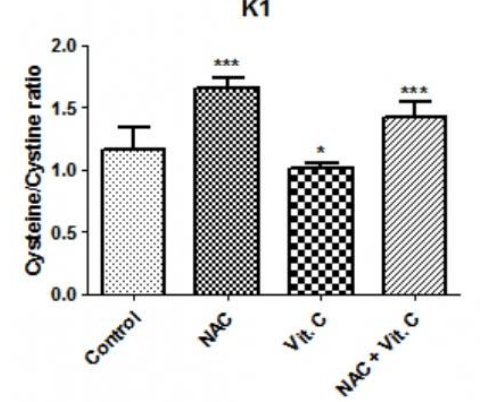

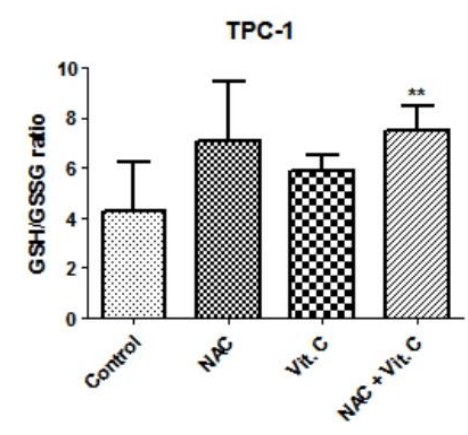

B-CPAP

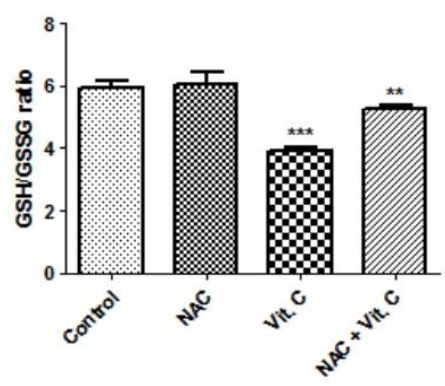

TPC-1
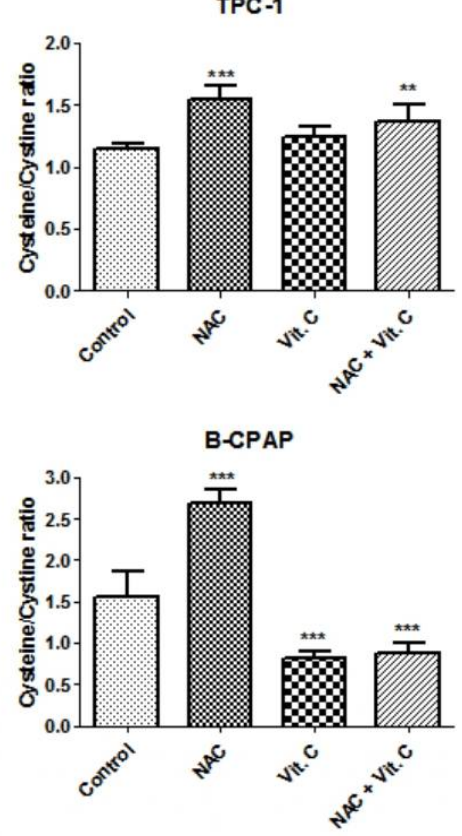

Figure 4. Levels of GSH/GSSG ratio (A) in PTC-derived cell lines and control cell line and levels of Cys /CySS ratio (B) after $24 \mathrm{~h}$ of incubation with vitamin $\mathrm{C}$ alone $(5 \mathrm{mM})$ or in combination with NAC 
(10 mM). Peak areas of intracellular aminothiols were normalized using protein contents (ng of aminothiols per $\mu \mathrm{g}$ of proteins) and expressed as the ratio of reduced and oxidized forms. Data are expressed as Mean \pm SD. All experiments were performed three times independently, each time in triplicate to confirm the results. Statistical analysis was performed by Student $t$-test. Results were considered significant vs. control when ${ }^{*} p<0.05,{ }^{* *} p<0.01$, and ${ }^{* *} p<0.001$.

\subsection{NAC Effect on Vitamin C Induced Cell Death}

To investigate the effect of NAC in cytotoxicity induced by vitamin C, PTC-derived and control cell lines were treated with these agents alone or in combination and cell death was assessed by Annexin V/Propidium Iodide assay. As expected, exposure to vitamin C caused cell death by necrosis in 59.7\% B-CPAP and 33.9\% K1 and by apoptosis in $14.2 \%$ $\mathrm{B}-\mathrm{CPAP}$ and $11.0 \% \mathrm{~K} 1$. Interestingly, exposure to $5 \mathrm{mM}$ vitamin $\mathrm{C}$ in combination with NAC $(10 \mathrm{mM})$ caused cell death by necrosis in $8.6 \% \mathrm{~B}$-CPAP and $4.8 \% \mathrm{~K} 1$, and by apoptosis in 79.7\% B-CPAP and $45.2 \% \mathrm{~K} 1$. In TPC-1 and Nthy-ori3-1 control cells, only cell death by apoptosis was observed at a low percentage $(<10 \%)$ after exposure to vitamin $\mathrm{C}$ alone or in combination with NAC (Figure 5).

\subsection{Alterations in Energetic Metabolism in PTC-Derived Cells Induced by Vitamin C Treatment}

To investigate the effect of vitamin $C$ on energy metabolism, a metabolomic-based approach was used to identify metabolic changes in $B R A F$ mutant thyroid cancer cells following vitamin $C$ treatment. Since in BRAF wild-type thyroid cancer cells (TPC-1) and control cells (Nthy-ori3-1) exposure to $5 \mathrm{mM}$ vitamin $C$ did not affect $R O S$ perturbations and exhibited low sensitivity to cytotoxic effect, the analysis of metabolic profiles was restricted to B-CPAP and K1 cells. Glucose uptake and metabolites involved in glycolysis, TCA cycle, and $\mathrm{NAD}^{+}$salvage pathways were evaluated in these cells after $24 \mathrm{~h}$ of vitamin $\mathrm{C}$ treatment. Exposure to vitamin $C$ significantly reduced the glucose uptake in PTC-derived cells (Figure 6A) and altered various metabolites in glycolysis and TCA cycle. In particular, in both cell lines, glucose, fructose biphosphate, and glyceraldehyde 3-phosphate were significantly increased in treated cells; dihydroxyacetone phosphate was found at very high levels in $\mathrm{K} 1$ cells exposed to vitamin $\mathrm{C}$ whereas a slight increase was observed in BCPAP cells without reaching statistical significance (Figure 6B). On the contrary, glycolysis downstream metabolites (2/3-phosphoglycerate, phosphoenolpyruvate) were decreased in both cell lines but only in K1 were they significantly reduced.

In the TCA cycle, coenzyme A was significantly increased in both vitamin $C$ treated cell lines, whereas acetyl-CoA was significantly reduced only in B-CPAP cells (Figure 6C). The downstream metabolites, such as succinate, fumarate, and malate were significantly increased in vitamin $C$ exposed cells while oxalacetate was found significantly elevated only in $\mathrm{K} 1$ cell lines (Figure $6 \mathrm{C}$ ). Furthermore, metabolites belonging to the $\mathrm{NAD}^{+}$salvage pathway were significantly decreased in treated cancer cells. In particular, vitamin $C$ treatment caused a significant decrease of nicotinamide and $\mathrm{NAD}^{+}$in B-CPAP and K1 (Figure 6D). The summary of the oxidative and metabolic effects of vitamin $C$ is shown in Figure 7. Collectively these results suggest that in thyroid cancer cell lines vitamin C can induce oxidative stress and impairment of glycolysis with reduction of $\mathrm{NAD}^{+}$levels ultimately leading to cell death. 


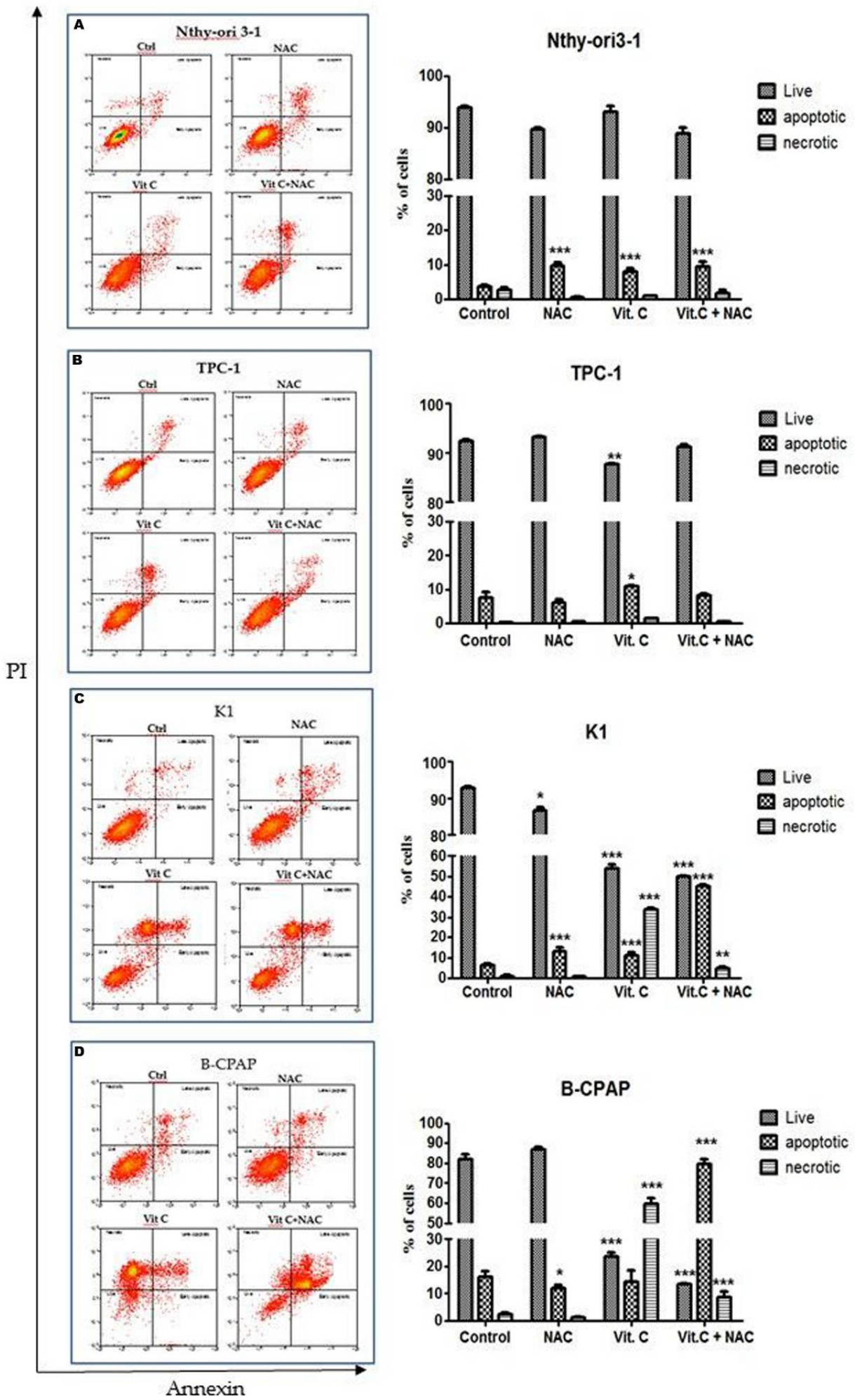

Figure 5. Percentage of live, apoptotic, and necrotic cells measured by flow cytometry using the PIannexin V assay. All cell lines were exposed to $5 \mathrm{mM}$ of vitamin C or NAC (10 mM) or a combination of both agents for $48 \mathrm{~h}$. Dot plots showing cell death in Nthy-ori3-1 (A), TPC-1 (B), K1 (C), and B-CPAP cells (D). Pictures are representative of three experiments. Bar graphs represented the percentage of live, apoptotic (early apoptotic and late apoptotic cells), and necrotic cells. Data are expressed as Mean of \% cells \pm SD. All experiments were performed three times independently, each time in triplicate, to confirm the results. Statistical analyses were performed by Student $t$-test. Statistical differences vs. control are expressed with superscript symbols: ${ }^{*} p<0.05$; ${ }^{* *} p<0.01$; *** $p<0.001$. 
A

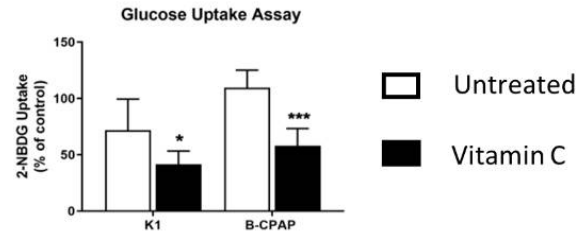

B
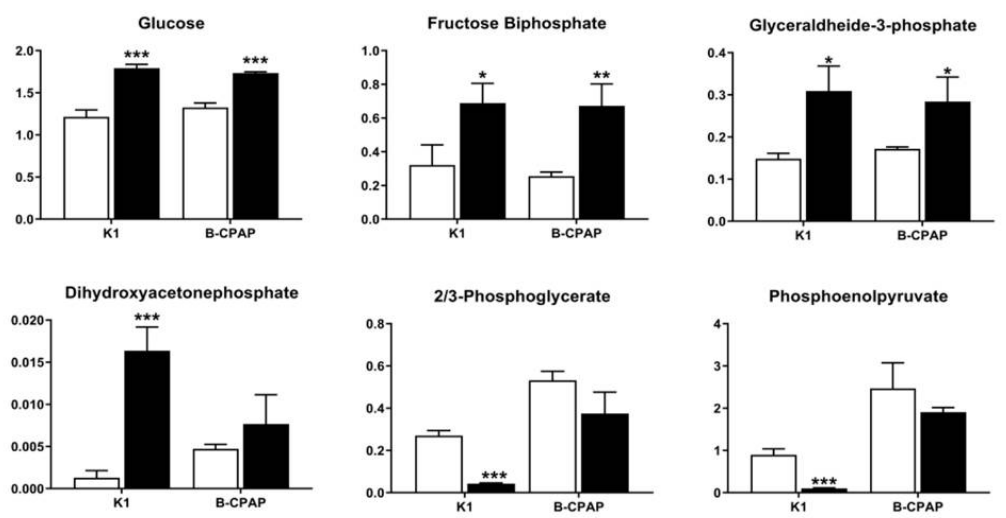

C
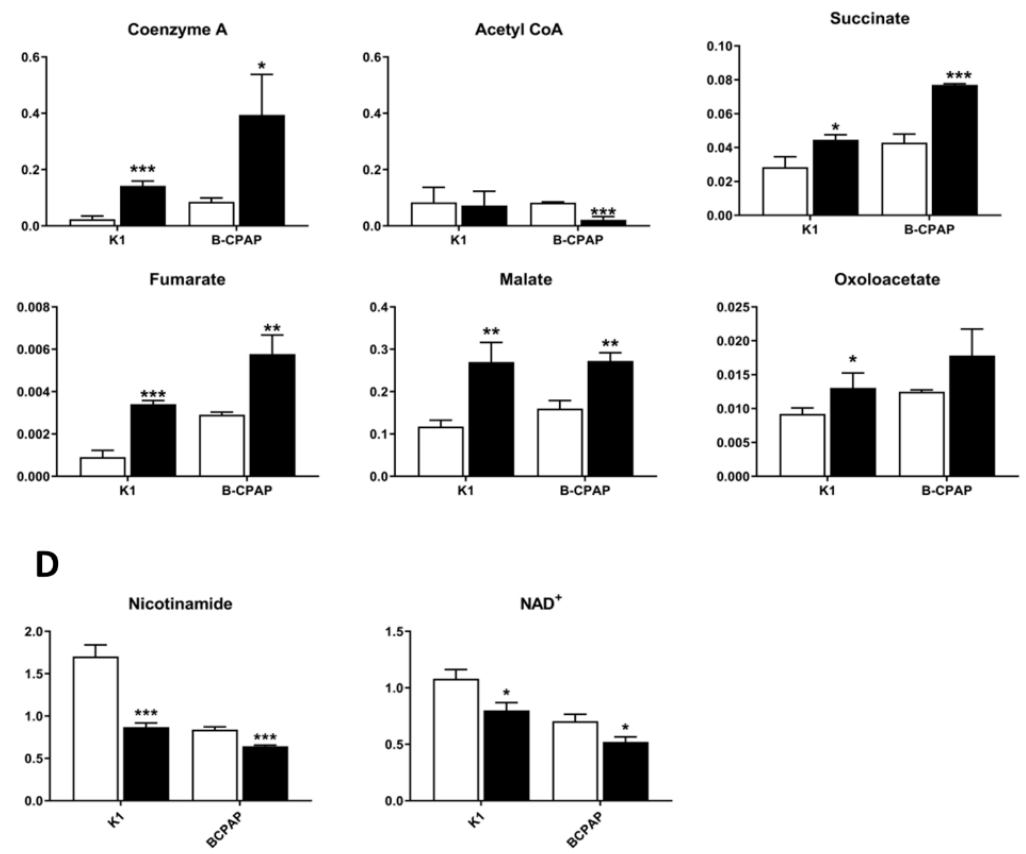

Figure 6. Metabolic alterations induced by vitamin C. (A) Quantification of the relative glucose uptake was done through the fluorescent glucose analog 2-NBDG in cancer cells treated with vitamin C. Data are expressed as media \pm SD. (B) Intracellular levels of glycolytic pathway; (C) TCA cycle; (D) $\mathrm{NAD}^{+}$salvage pathway, and ATP level. Metabolites were measured after $24 \mathrm{~h}$ of incubation with vitamin C. Bar graphs indicate the peak areas of the metabolites, normalized for total area, and expressed in the graphs as ranks. All experiments were performed three times independently, each time in triplicate, to confirm the results. Statistical analyses were performed by Student $t$-test. Results were considered significant when: ${ }^{*} p<0.05 ;{ }^{* *} p<0.01$; ${ }^{* *} p<0.001$. 


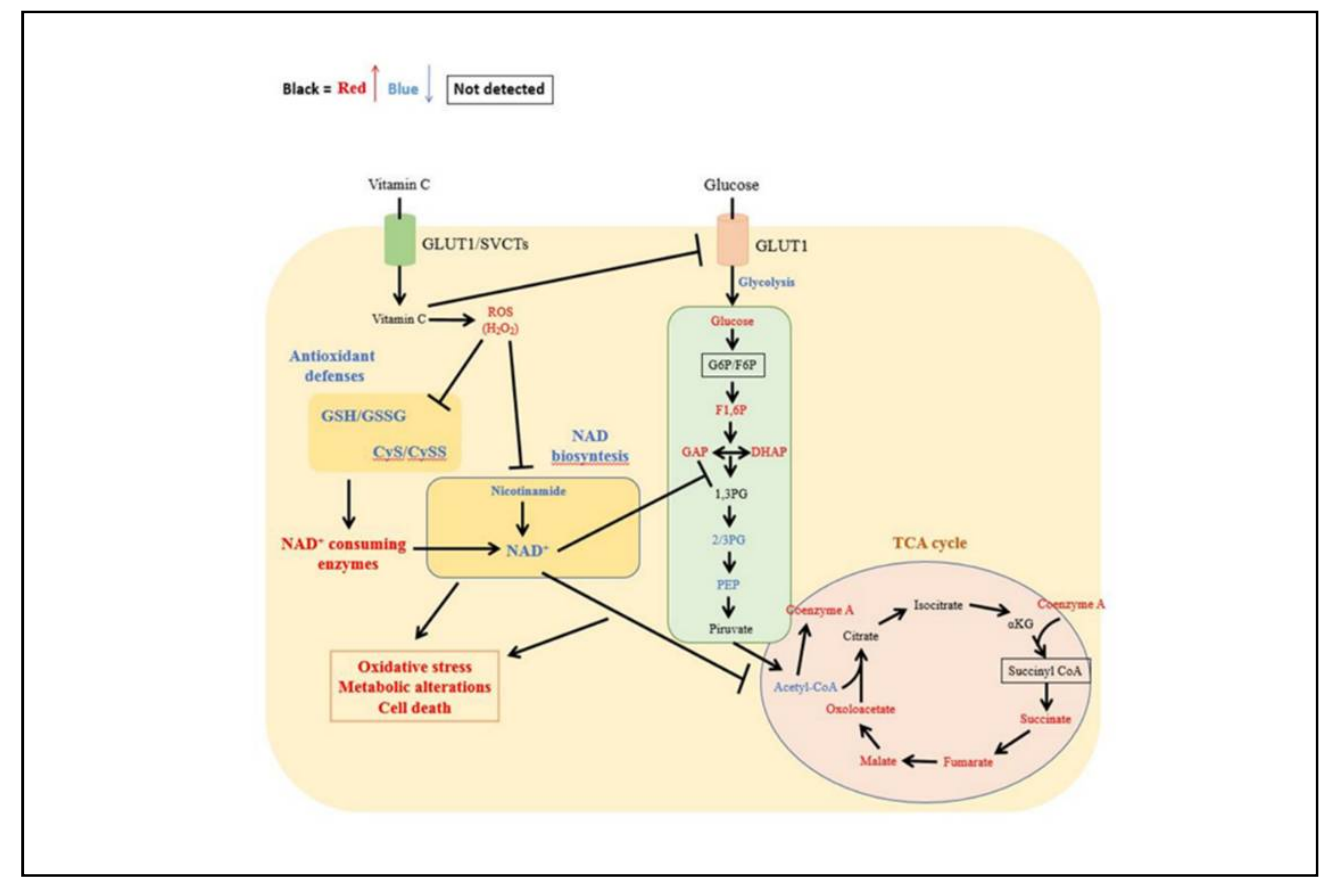

Figure 7. Summary of the effect of a high dose of vitamin C in B-CPAP and K1 cells. Vitamin C induces oxidative stress by increasing ROS and therefore decreasing antioxidants. The decrease of GSH and CyS results in deregulation of the NAD ${ }^{+}$ biosynthesis and consequently in an impairment of energetic pathways, such as glycolysis and TCA cycle. Color coding indicates significantly different metabolites (red, upregulated; blue, downregulated; black, unchanged; boxed, not detected).

\section{Discussion}

Vitamin $C$ has been gaining growing attention as a potential treatment for human malignancies [21]. It is well known that vitamin $C$ can induce cell death by inducing oxidative stress in cancer cells [22], and there is a growing interest to clarify the cellular mechanisms underlying this effect. Recently, it has been suggested that there is an important relationship between vitamin C pro-oxidant effects and cancer metabolisms in several tumors, such as breast, liver cancers, and leukemia [4,23,24]. This biological link produces dysregulation of several energetic pathways, such as glycolysis, TCA cycle, and pentose phosphate pathway $[4,25]$. This aspect has not been fully investigated so far in thyroid cancer. In this study, we focused our attention particularly on the cytotoxicity of vitamin C and the modulation of metabolism and redox homeostasis in PTC-derived cell lines harboring different genetic backgrounds [14]. The experiments were carried out on TPC-1 with RET/PTC1 rearrangement, $\mathrm{K} 1$ and B-CPAP harboring $B R A F^{V 600 E}$ mutation (in heterozygosis and homozygosis, respectively) [26]. Nthy-ori3.1 cells, derived from human follicular epithelial cells and negative for the above-mentioned alterations, were used as control.

Vitamin C inhibited the growth of PTC and control cells with different susceptibility to the vitamin $C$ treatment (from the less sensitive: Nthy-ori3-1 > TPC-1 > B-CPAP and K1).

It is well known that thyroid hormone synthesis requires hydrogen peroxide $\left(\mathrm{H}_{2} \mathrm{O}_{2}\right)$ as an oxidative agent. In particular, the process is called "iodide organification", where specific tyrosine residues of thyroglobulin (TG) undergo iodination oxidative by the enzyme thyroid peroxidase (TPO). The $\mathrm{H}_{2} \mathrm{O}_{2}$ is usually generated by oxidase proteins (DUOX1 and DUOX2) [27]. In a stable human TPO-expressing cell lines, TPO protect DUOX2 from inhibition of $\mathrm{H}_{2} \mathrm{O}_{2}$ by a catalase-like activity, regulating the level of extracellular $\mathrm{H}_{2} \mathrm{O}_{2}$ probably by decreasing the oxidative damage of macromolecules [28]. Buettner's group demonstrated that a high dose of vitamin $C$ (in the millimolar range) selectively kills cancer cells but not normal cells, because the tumor cells are much less efficient in removing hydrogen peroxide than normal cells. They show that cells with lower amounts 
of catalase activity were more susceptible to damage and death when they were exposed to high amounts of vitamin C [29]. In our study, Nthy-ori3-1 cells are less susceptible at the higher $(15 \mathrm{mM})$ and lower $(5 \mathrm{mM})$ of the vitamin $C$ concentrations tested. We can suppose that these cells, where TPO is expressed [30], possess a high level of enzymes involve in removing hydrogen peroxide generated from high dose of vitamin $\mathrm{C}$. Therefore, this compound exerted a high cytotoxic activity in PTC cells compared to control cells, even supporting previous studies about the selectively cytotoxic effect of vitamin $C$ in cancer cells harboring KRAS or BRAF mutations $[9,11]$. Moreover, it has been demonstrated that aberrant activation of the MAPK pathway related to $B R A F$ mutations is crucial in the damage of the iodide-handling machinery [31], so a high cytotoxic activity of vitamin $C$ in $\mathrm{B}-\mathrm{CPAP}$ and $\mathrm{K} 1$ with $B R A F$ mutation could be associated with a decrease of the expression of genes involved in thyroid hormone biosynthesis in these cells [32].

Different studies reported that a high concentration of vitamin $C$ induces cell death by apoptosis in various cancer cells [33]. Our results by FACS analysis showed that apoptosis occurred in control cells and necrosis in PTC cells after exposure to vitamin C. Moreover, when the lower concentration of vitamin $C(5 \mathrm{mM})$ was used, a small fraction of TPC-1 and control cells died by apoptosis, while in $\mathrm{K} 1$ and $\mathrm{B}-\mathrm{CPAP}$, more necrotic cells were detected as compared to the control. Interestingly, the combinatory treatment with vitamin $\mathrm{C}$ and NAC lead to a change in the type of cell death of B-CPAP and K1 cell lines shifting from necrosis induced by vitamin $C$ alone to apoptosis induced by exposure to both agents. This observation could be explained by NAC capability to counteract the alteration in redox homeostasis induced by vitamin C. However, the induction of apoptosis can be assumed to be linked to the effects of vitamin C on DNA demethylation. Indeed, vitamin $C$ is known to act as an essential cofactor to numerous monooxygenases and dioxygenases, including the ten-eleven translocation (TET) enzyme family, which catalyzes the hydroxylation of 5 -methylcytosine $(5 \mathrm{mC})$ to 5 -hydroxymethylcytosine $(5 \mathrm{hmC})$ in the active process of DNA demethylation $[34,35]$. This mechanism leads to the reactivation and upregulation of proapoptotic genes, which are conversely downregulated in those cells harboring KRAS and BRAF mutations, which are in turn known to limit DNA demethylation [36-38].

In our experiments, vitamin $C$ increased ROS production only in B-CPAP cells, and this increment was reduced when vitamin $C$ was challenged with NAC. As expected, in B-CPAP the increase in ROS production resulted in a depletion of antioxidants, as demonstrated by the decrease of GSH/GSSG and CyS/CySS ratios. In addition, although ROS production in K1 cells was not significantly higher than untreated cells, the depletion of CyS stocks was also verified, maybe due to higher sensitivity to ROS oxidative action of this cell line. Our data showed that treatments with vitamin $C$ affected mainly the Cys/CySS ratio, suggesting an increased demand for antioxidants, such as GSH, likely due to the high requirement of cysteine for glutathione biosynthesis [39]. Moreover, possibly as a consequence of redox homeostasis unbalance, we observed a metabolic perturbation induced by a high dose of vitamin C in B-CPAP and $\mathrm{K} 1$ cells. Indeed, the results showed increased levels of upstream metabolites of glycolysis, suggesting an accumulation of these intermediates inside the cells. This outcome was verified even though glucose uptake was partially inhibited by vitamin $C$ treatments. Indeed, our results showed that exposure to a high-dose of vitamin $C$ resulted in a decrease of relative glucose uptake in PTC-derived and control cells. This could be linked to the fact that vitamin $C$ usually undergoes uptake by cells, before oxidation by dehydroascorbate, through GLUT transporters, due to its chemical structural similarity with glucose [40]. In agreement with this point, recent studies showed in fact that GLUT1 expression is much higher in K1 and B-CPAP cells compared to the control cells $[11,41]$. The accumulation of glucose and structurally related metabolites may be explained by an impairment of glycolysis, which resulted in decreased downstream metabolites levels. This reduction could be associated with the decrease of $\mathrm{NAD}^{+}$content in PTC-derived cell with $B R A F$ mutations, due to vitamin $C$ treatment and its oxidative action as previously well explained by Uetaki et al., [4]. This pathway is fundamental for various cellular processes, including energy metabolism [42]. The depletion of $\mathrm{NAD}^{+}$resulted 
also in a perturbation of TCA cycle: the upstream metabolites were not significantly regulated, while downstream metabolites were increased. The alteration of glycolysis and TCA cycle is supposed to be responsible for $\mathrm{NAD}^{+}$decrease, confirming what was reported by Uetaki et al., [4]. Furthermore, it has been proposed that high doses of vitamin $C$ may affect mitochondrial homeostasis. In particular, Bakalova and colleagues described the central role of the ascorbyl free radical (AFR) in mediating impairment of mitochondrial respiration [43]. AFR derived from the oxidation of ascorbate and may temporarily accumulate in cells $[44,45]$. The cytotoxic potential of AFR is strongly correlated with the activity of the NADH:cyto chrome-b5-oxidoreductase-3 (Cyb5R3) which catalyzes rapid conversion of AFR to ascorbate. Cyb5R3 is overexpressed in breast cancer and correlate with poor disease-free and overall survival [46]. Furthermore, increased Cyb5R3 activity is observed in papillary thyroid cancer compared to follicular adenomas [47]. It has been hypothesized that a high intracellular concentration of vitamin $\mathrm{C}$ may induce Cyb5R3 activity inhibition, leading to increased level of AFR in the mitochondrial intermembrane space and decreased level of the NAD+/NADH ratio in the cytosol. AFR may also interact with cytochrome $\mathrm{C}$, causing a partial or complete arrest of electron flow in mitochondrial complex and impairing mitochondrial respiration [43]. It could be hypothesized that the same mechanism occurs also in B-CPAP and K1 BRAF-mutated cancer cells but this remaining issue requires experimental verification.

\section{Conclusions}

Taken together, our data confirmed that vitamin $C$ can induce ROS production and depletion of antioxidant defenses in PTC cells harboring $B R A F^{V 600}$ mutation but not in cells characterized by RET/PTC rearrangements, reinforcing the idea that this compound exerts a selective effect in tumor cells with specific mutations. Moreover, we pointed out that a high concentration of vitamin C has an anti-tumoral effect in PTC cells, by altering redox homeostasis which had an impact on the NAD salvage pathway, resulting in turn in glycolysis and TCA cycle impairment, and finally inducing cell death. Howsoever, further investigations, including in vivo studies, are needed to better elucidate the mechanisms involved in the cytotoxic action of vitamin C in PTC-derived cells, to promote its potential use as anti-tumoral compound.

Author Contributions: Conceptualization, L.T., P.C., R.V., and L.A.; methodology, L.T. and P.C.; formal analysis, L.T., G.S., and P.C.; investigation, L.T., G.S., C.P., D.V.F., T.D., F.M., M.L.S., M.S., J.L.G., and P.C.; data curation, L.T., G.S., P.C., M.D., L.A., V.P.L. and R.V.; writing-original draft preparation, L.T., G.S., P.C., and V.P.L.; writing-review and editing, L.T., G.S., P.C., and V.P.L.; visualization, R.V., L.A., and M.D.; supervision, R.V., L.A., and M.D. All authors have read and agreed to the published version of the manuscript.

Funding: This research received no external funding.

Data Availability Statement: The data presented in this study are showed in this paper.

Acknowledgments: We acknowledge the CeSAR (Centro Servizi Ricerca d'Ateneo) core facility of the University of Cagliari and Rita Pillai for assistance with the generation of the flow cytometry data.

Conflicts of Interest: The authors declare no conflict of interest.

\section{References}

1. Verrax, J.; Calderon, P.B. Pharmacologic concentrations of ascorbate are achieved by parenteral administration and exhibit antitumoral effects. Free Radic. Biol. Med. 2009, 47, 32-40. [CrossRef]

2. Lv, H.; Wang, C.; Fang, T.; Li, T.; Lv, G.; Han, Q.; Yang, W.; Wang, H. Vitamin C preferentially kills cancer stem cells in hepatocellular carcinoma via SVCT-2. NPJ Precis Oncol. 2018, 2, 1. [CrossRef]

3. Chen, X.Y.; Chen, Y.; Qu, C.J.; Pan, Z.H.; Qin, Y.; Zhang, X.; Liu, W.J.; Li, D.F.; Zheng, Q. Vitamin C induces human melanoma A375 cell apoptosis via Bax- and Bcl-2-mediated mitochondrial pathways. Oncol. Lett. 2019, 18, 3880-3886. [CrossRef] [PubMed]

4. Uetaki, M.; Tabata, S.; Nakasuka, F.; Soga, T.; Tomita, M. Metabolomic alterations in human cancer cells by vitamin C-induced oxidative stress. Sci. Rep. 2015, 5, 13896. [CrossRef] [PubMed] 
5. Takemura, Y.; Satoh, M.; Satoh, K.; Hamada, H.; Sekido, Y.; Kubota, S. High dose of ascorbic acid induces cell death in mesothelioma cells. Biochem. Biophys. Res. Commun. 2010, 394, 249-253. [CrossRef] [PubMed]

6. Du, J.; Cullen, J.J.; Buettner, G.R. Ascorbic acid: Chemistry, biology and the treatment of cancer. Biochim. Biophys. Acta 2012, 1826, 443-457. [CrossRef] [PubMed]

7. Chen, Q.; Espey, M.G.; Sun, A.Y.; Pooput, C.; Kirk, K.L.; Krishna, M.C.; Khosh, D.B.; Drisko, J.; Levine, M. Pharmacologic doses of ascorbate act as a prooxidant and decrease growth of aggressive tumor xenografts in mice. Proc. Natl. Acad. Sci. USA 2008, 105, 11105-11109. [CrossRef] [PubMed]

8. Cairns, R.A.; Harris, I.S.; Mak, T.W. Regulation of cancer cell metabolism. Nat. Rev. Cancer 2011, 11, 85-95. [CrossRef]

9. Yun, J.; Mullarky, E.; Lu, C.; Bosch, K.N.; Kavalier, A.; Rivera, K.; Roper, J.; Chio, I.I.C.; Giannopoulou, E.G.; Rago, C.; et al. Vitamin C selectively kills KRAS and BRAF mutant colorectal cancer cells by targeting GAPDH. Science 2015, 350, 1391-1396. [CrossRef]

10. Costa, V.; Esposito, R.; Pallante, P.; Ciccodicola, A.; Fusco, A. The "next-generation" knowledge of papillary thyroid carcinoma. Cell Cycle 2015, 14, 2018-2021. [CrossRef]

11. Su, X.; Shen, Z.; Yang, Q.; Sui, F.; Pu, J.; Ma, J.; Ma, S.; Yao, D.; Ji, M.; Hou, P. Vitamin C kills thyroid cancer cells through ROS-dependent inhibition of MAPK/ERK and PI3K/AKT pathways via distinct mechanisms. Theranostics 2019, 9, 4461-4473. [CrossRef] [PubMed]

12. Biersack, H.-J.; Grünwald, F. Thyroid Cancer; Springer: Berlin, Germany, 2005. [CrossRef]

13. Maric, I.; Viaggi, S.; Caria, P.; Frau, D.V.; Degan, P.; Vanni, R. Centrosomal and mitotic abnormalities in cell lines derived from papillary thyroid cancer harboring specific gene alterations. Mol. Cytogenet. 2011, 4, 26. [CrossRef]

14. Caria, P.; Pillai, R.; Dettori, T.; Frau, D.V.; Zavattari, P.; Riva, G.; Romano, G.; Pani, F.; Bentivegna, A.; Giovannoni, R.; et al. Thyrospheres from B-CPAP Cell Line with BRAF and TERT Promoter Mutations have Different Functional and Molecular Features than Parental Cells. J. Cancer 2017, 8, 1629-1639. [CrossRef]

15. Barberis, A.; Deiana, M.; Spissu, Y.; Azara, E.; Fadda, A.; Serra, P.A.; D’hallewin, G.; Pisano, M.; Serreli, G.; Orrù, G.; et al. Antioxidant, Antimicrobial, and Other Biological Properties of Pompia Juice. Molecules 2020, 25, 3186. [CrossRef] [PubMed]

16. Dinicola, S.; Mariggio, M.A.; Morabito, C.; Guarnieri, S.; Cucina, A.; Pasqualato, A.; D’Anselmi, F.; Proietti, S.; Coluccia, P.; Bizzarri, M. Grape seed extract triggers apoptosis in Caco-2 human colon cancer cells through reactive oxygen species and calcium increase: Extracellular signal-regulated kinase involvement. Br. J. Nutr. 2013, 110, 797-809. [CrossRef] [PubMed]

17. Serreli, G.; Incani, A.; Atzeri, A.; Angioni, A.; Campus, M.; Cauli, E.; Zurru, R.; Deiana, M. Antioxidant Effect of Natural Table Olives Phenolic Extract Against Oxidative Stress and Membrane Damage in Enterocyte-Like Cells. J. Food Sci. 2017, 82, 380-385. [CrossRef]

18. Khan, A.; Khan, M.I.; Iqbal, Z.; Shah, Y.; Ahmad, L.; Nazir, S.; Watson, D.G.; Khan, J.A.; Nasir, F.; Khan, A.; et al. A new HPLC method for the simultaneous determination of ascorbic acid and aminothiols in human plasma and erythrocytes using electrochemical detection. Talanta 2011, 84, 789-801. [CrossRef] [PubMed]

19. Incani, A.; Serra, G.; Atzeri, A.; Melis, M.P.; Serreli, G.; Bandino, G.; Sedda, P.; Campus, M.; Tuberoso, C.I.; Deiana, M. Extra virgin olive oil phenolic extracts counteract the pro-oxidant effect of dietary oxidized lipids in human intestinal cells. Food Chem. Toxicol. 2016, 90, 171-180. [CrossRef]

20. Caria, P.; Tronci, L.; Dettori, T.; Murgia, F.; Santoru, M.L.; Griffin, J.L.; Vanni, R.; Atzori, L. Metabolomic Alterations in Thyrospheres and Adherent Parental Cells in Papillary Thyroid Carcinoma Cell Lines: A Pilot Study. Int. J. Mol. Sci. 2018, 19, 2948. [CrossRef]

21. Vissers, M.C.M.; Das, A.B. Potential Mechanisms of Action for Vitamin C in Cancer: Reviewing the Evidence. Front. Physiol. 2018, 9, 809. [CrossRef]

22. Park, S.; Han, S.S.; Park, C.H.; Hahm, E.R.; Lee, S.J.; Park, H.K.; Lee, S.H.; Kim, W.S.; Jung, C.W.; Park, K.; et al. L-Ascorbic acid induces apoptosis in acute myeloid leukemia cells via hydrogen peroxide-mediated mechanisms. Int. J. Biochem. Cell Biol. 2004, 36, 2180-2195. [CrossRef] [PubMed]

23. Harakeh, S.; Diab-Assaf, M.; Khalife, J.C.; Abu-el-Ardat, K.A.; Baydoun, E.; Niedzwiecki, A.; El-Sabban, M.E.; Rath, M. Ascorbic acid induces apoptosis in adult T-cell leukemia. Anticancer Res. 2007, 27, 289-298. [PubMed]

24. Gao, X.; Wei, K.; Hu, B.; Xu, K.; Tang, B. Ascorbic acid induced HepG2 cells' apoptosis via intracellular reductive stress. Theranostics 2019, 9, 4233-4240. [CrossRef] [PubMed]

25. Park, S.; Ahn, S.; Shin, Y.; Yang, Y.; Yeom, C.H. Vitamin C in Cancer: A Metabolomics Perspective. Front. Physiol. 2018, 9 , 762. [CrossRef]

26. Caria, P.; Dettori, T.; Frau, D.V.; Lichtenzstejn, D.; Pani, F.; Vanni, R.; Mai, S. Characterizing the three-dimensional organization of telomeres in papillary thyroid carcinoma cells. J. Cell Physiol. 2019, 234, 5175-5185. [CrossRef]

27. Grasberger, H.; Refetoff, S. Identification of the maturation factor for dual oxidase. Evolution of an eukaryotic operon equivalent J. Biol. Chem. 2006, 281, 18269-18272. [CrossRef]

28. Fortunato, R.S.; Lima de Souza, E.C.; Ameziane-el Hassani, R.; Boufraqech, M.; Weyemi, U.; Talbot, M.; Lagente-Chevallier, O.; de Carvalho, D.P.; Bidart, J.M.; Schlumberger, M.; et al. Functional consequences of dual oxidase-thyroperoxidase interaction at the plasma membrane. J. Clin. Endocrinol. Metab. 2010, 95, 5403-5411. [CrossRef]

29. Doskey, C.M.; Buranasudja, V.; Wagner, B.A.; Wilkes, J.G.; Du, J.; Cullen, J.J.; Buettner, G.R. Tumor cells have decreased ability to metabolize H2O2: Implications for pharmacological ascorbate in cancer therapy. Redox Biol. 2016, 10, 274-284. [CrossRef] 
30. Godlewska, M.; Krasuska, W.; Czarnocka, B. Biochemical properties of thyroid peroxidase (TPO) expressed in human breast and mammary-derived cell lines. PLoS ONE 2018, 13, e0193624. [CrossRef]

31. Xing, M. BRAF mutation in papillary thyroid cancer: Pathogenic role, molecular bases, and clinical implications. Endocr. Rev. 2007, 28, 742-762. [CrossRef]

32. Schweppe, R.E.; Klopper, J.P.; Korch, C.; Pugazhenthi, U.; Benezra, M.; Knauf, J.A.; Fagin, J.A.; Marlow, L.A.; Copland, J.A.; Smallridge, R.C.; et al. Deoxyribonucleic acid profiling analysis of 40 human thyroid cancer cell lines reveals cross-contamination resulting in cell line redundancy and misidentification. J. Clin. Endocrinol. Metab. 2008, 93, 4331-4341. [CrossRef] [PubMed]

33. Hong, S.-W.; Jin, D.-H.; Hahm, E.-S.; Yim, S.-H.; Lim, J.-S.; Kim, K.-I.; Yang, Y.; Lee, S.-S.; Kang, J.-S.; Lee, W.-J.; et al. Ascorbate (vitamin C) induces cell death through the apoptosis-inducing factor in human breast cancer cells. Oncol. Rep. 2007. [CrossRef]

34. Shorey-Kendrick, L.E.; McEvoy, C.T.; Ferguson, B.; Burchard, J.; Park, B.S.; Gao, L.; Vuylsteke, B.H.; Milner, K.F.; Morris, C.D.; Spindel, E.R. Vitamin C Prevents Offspring DNA Methylation Changes Associated with Maternal Smoking in Pregnancy. Am. J. Respir Crit. Care Med. 2017, 196, 745-755. [CrossRef] [PubMed]

35. Camarena, V.; Wang, G. The epigenetic role of vitamin C in health and disease. Cell Mol. Life Sci. 2016, 73, 1645-1658. [CrossRef] [PubMed]

36. Wong, C.C.; Xu, J.; Bian, X.; Wu, J.L.; Kang, W.; Qian, Y.; Li, W.; Chen, H.; Gou, H.; Liu, D.; et al. In Colorectal Cancer Cells With Mutant KRAS, SLC25A22-Mediated Glutaminolysis Reduces DNA Demethylation to Increase WNT Signaling, Stemness, and Drug Resistance. Gastroenterology 2020, 159, 2163-2180. [CrossRef] [PubMed]

37. Bond, C.E.; Liu, C.; Kawamata, F.; McKeone, D.M.; Fernando, W.; Jamieson, S.; Pearson, S.A.; Kane, A.; Woods, S.L.; Lannagan, T.R.M.; et al. Oncogenic BRAF mutation induces DNA methylation changes in a murine model for human serrated colorectal neoplasia. Epigenetics 2018, 13, 40-48. [CrossRef]

38. Gopisetty, G.; Ramachandran, K.; Singal, R. DNA methylation and apoptosis. Mol. Immunol. 2006, 43, 1729-1740. [CrossRef]

39. Cramer, S.L.; Saha, A.; Liu, J.; Tadi, S.; Tiziani, S.; Yan, W.; Triplett, K.; Lamb, C.; Alters, S.E.; Rowlinson, S.; et al. Systemic depletion of L-cyst(e)ine with cyst(e)inase increases reactive oxygen species and suppresses tumor growth. Nat. Med. 2017, 23, 120-127. [CrossRef]

40. Rumsey, S.C.; Kwon, O.; Xu, G.W.; Burant, C.F.; Simpson, I.; Levine, M. Glucose transporter isoforms GLUT1 and GLUT3 transport dehydroascorbic acid. J. Biol. Chem. 1997, 272, 18982-18989. [CrossRef]

41. Tronci, L.; Caria, P.; Frau, D.V.; Liggi, S.; Piras, C.; Murgia, F.; Santoru, M.L.; Pibiri, M.; Deiana, M.; Griffin, J.L.; et al. Crosstalk between Metabolic Alterations and Altered Redox Balance in PTC-Derived Cell Lines. Metabolites 2019, 9, 23. [CrossRef]

42. Kennedy, B.E.; Sharif, T.; Martell, E.; Dai, C.; Kim, Y.; Lee, P.W.; Gujar, S.A. NAD(+) salvage pathway in cancer metabolism and therapy. Pharmacol. Res. 2016, 114, 274-283. [CrossRef]

43. Bakalova, R.; Zhelev, Z.; Miller, T.; Aoki, I.; Higashi, T. Vitamin C versus Cancer: Ascorbic Acid Radical and Impairment of Mitochondrial Respiration? Oxid. Med. Cell. Longev. 2020, 2020, 1504048. [CrossRef] [PubMed]

44. Smirnoff, N. Ascorbic acid metabolism and functions: A comparison of plants and mammals. Free Radic. Biol. Med. 2018, 122, 116-129. [CrossRef] [PubMed]

45. Ngo, B.; Van Riper, J.M.; Cantley, L.C.; Yun, J. Targeting cancer vulnerabilities with high-dose vitamin C. Nat. Rev. Cancer 2019, 19, 271-282. [CrossRef] [PubMed]

46. Lund, R.R.; Leth-Larsen, R.; Caterino, T.D.; Terp, M.G.; Nissen, J.; Laenkholm, A.V.; Jensen, O.N.; Ditzel, H.J. NADH-Cytochrome b5 Reductase 3 Promotes Colonization and Metastasis Formation and Is a Prognostic Marker of Disease-Free and Overall Survival in Estrogen Receptor-Negative Breast Cancer. Mol. Cell. Proteom. 2015, 14, 2988-2999. [CrossRef] [PubMed]

47. Proskurnina, E.V.; Fedorova, M.V.; Sozarukova, M.M.; Mitichkin, A.E.; Panteleev, I.V.; Svetlov, E.V. Microsomal reductase activity in patients with thyroid neoplasms. Endocrine 2020. [CrossRef] 